\title{
Marketing Pattern and Constraints of Banana Production in Bemetara District of Chhattisgarh, India
}

\author{
Ashish Patel*, Shashank Sharma, Anjali Verma and Yogeshwari Sahu \\ Department of Agricultural Economics, College of Agriculture, IGKV, Raipur, India \\ *Corresponding author
}

\begin{tabular}{l} 
K e y w o r d s \\
$\begin{array}{l}\text { Marketable surplus, } \\
\text { marketing channel }\end{array}$ \\
\hline Article Info \\
\hline $\begin{array}{l}\text { Accepted: } \\
\text { 18 May } 2020 \\
\text { Available Online: } \\
\text { 10 June } 2020\end{array}$ \\
\hline
\end{tabular}

\section{A B S T R A C T}

The present study was carried out to determine the marketing pattern of banana in Bemetara district of Chhattisgarh. A list of banana growing villages has been prepared and atleast 28 villages with atleast 4 banana growers are randomly selected for study purposes and multistage sampling was adopted. A sample of 112 farmers was taken in which 20, 48 and 44 farmers are small, medium and large respectively. Detailed investigation was carried out to examine marketable surplus, marketing channel and producer's share in consumer's rupee through well prepared schedule in Bemetara district. It was identified that the highest marketable surplus in large farms was 1240.18 qt./farm, followed by the medium 406.45 qt./farm and the lowest in small farms as 208 qt./ farm. There are 3 marketing channels, from which channel-I is only used by the small farms in which the product was sold directly to the consumers or sold as a retailer on the nearest market. The most commonly used marketing channel across all three sample farms was channel-III in which the goods are marketed in field condition to the entire seller. The total quantity sold was 7.14, 208.72 and 482.67 via Channel-I, Channel-II and Channel-III. qt./ Farm in small, medium and large farms respectively. The share of producer in consumer's rupee was $95 \%, 77.56 \%$ and $73.4 \%$ respectively in channel I, channel II and channel III respectively.

\section{Introduction}

Banana is one of the oldest and the world's most important fruit crops cultivated by man from pre-historic times. A reference to the Banana in India frequently occurs in the Vedic literature, where mention is made of its use in religious rituals. It is a very popular fruit due to its low price and high nutritive value with rich source of carbohydrate and vitamins. It helps in reducing risk of heart diseases so, banana has and honorable place on the dining table of any common household. It is a very good natural preservative and indispensable ingredient of Indian medicine system, like Ayurveda. All the parts of the plant are used hence, Banana is named as plant of virtues (Kalpataru). Modern edible banana varieties have been evolved from the two species Musa accuminata and balbisiana. Today it becomes leading tropical fruit in the world market with a highly organized and developed industry. 
India is the second largest producer of fruit in the world and Banana ranks first in production occupying an area of about 802.6 lakh hectares with an annual production of 297.24 lakh tones and third in area among fruit crop (NHB 2013-14). It accounts for 11 per cent of the total area and 33 percent of the production of fruit (NHB 2013-14). Production is highest in Tamil Nadu (6736.4 thousand tones) followed by Maharastra (4315 thousand tones). The other major Banana producing states are Karnataka, Gujarat, and Punjab, Andhra Pradesh and Assam and Chhattisgarh. In Chhattisgarh the total area and production of fruits are 2.25 Lakh ha and 23.16 lakh MT in the year 201516 respectively. The production of fruits in Chhattisgarh, Banana rank first. The total production of Banana fruits in Chhattisgarh is 6.17 lakh metric tones. It is cultivated in almost all the districts in state. The major Banana growing districts are Raipur, Bilaspur, Durg, Mahasamund Bemetara. Banana production plays an important role in Chhattisgarh state.. The total area under Banana in Bemetara district is 950 hectare and 26.88 thousand metric tones production respectively (2015-16). It is estimated that, the present annual per capita consumption of banana in India is $50 \mathrm{~kg}$ per head which is very low compared with other progressive banana growing countries such as Jamaica, Congo, Equator, Kenya and Uganda. Thus there is an immense scope of increasing banana production in the country.

\section{Materials and Methods}

Simple random sampling technique is used in selection of block and villages and proportional random sampling technique are use in the selection of banana grower. Chhattisgarh state consist of 27 District out of which Bemetara district is selected purposively for the study because Bemetara district comes in the top five largest producer of banana in the Chhattisgarh with 950 hectare of area and 26884 MT of production under Banana. Productivity of banana in the District was also high with 28.29 tones /ha. There are 4 block in the district namely Saja, Bemetara, Berla and Nawagarh. The Banana fruit crops are grown in all the 4 blocks. However, Saja and Bemetara block selected purposely for the study purpose because saja and Bemetara block covers more than half area of banana in Bemetara district. Simple random sampling was used in selection of village. A list of Banana growing villages was prepared and then 28 villages, with at least 4 banana grower are selected randomly for the study purpose. Multistage sampling technique was adopted in selection of banana grower, 4 respondent from each of selected villages was selected and then categories into small medium and large farmer. Total 112 farmers was selected in which 20, 48, and 44 farmers are small medium and large. The data required for the study was primary in nature. The primary data were collected by personal interview. A interview schedule was developed as per objectives stated, for data collection each of the selected farmers was approached personally. The relevant information was gathered through pre-tested interview schedule and then the data were tabulated in the light of stated objectives. The Primary data in the study pertains to the agriculture year 2016-17.

\section{Analysis of data}

In order to fulfill the objectives of the study, the collected data was analyzed by using appropriate techniques and tools like marketing cost, marketing margin, price spread and marketing constraints.

\section{Results and Discussion}

\section{Marketing of banana}

Sample farmers sell their produce through three channels such as 


\section{Channel-I $=$ Producer $\rightarrow$ Consumer \\ Channel-II $=$ Producer $\rightarrow$ Commission $\rightarrow$ agent $\rightarrow$ Retailer $\rightarrow$ Consumer \\ Channel-III $=$ Producer $\rightarrow$ Whole $\rightarrow$ seller $\rightarrow$ Retailer $\rightarrow$ Consumer}

Disposal pattern and marketable surplus of banana

The disposal pattern of banana from different sample farms was also worked out, presented in table 4.10. The total production per farm was maximum in large farms (1243.68), overall being 701.39 qt. Small farms have more home consumption (0.95) as compared to medium and large farms. Marketable surplus was highest in large farms 1240.18 qt./farm followed by medium $406.45 \mathrm{q} / \mathrm{farm}$ and lowest in small farms as 208 qt./farm. There are 3 channels of marketing, out of which channel I is used only by the small farms in which the product was directly sold to the consumers in field or sell in the nearest market as a retailer. The most used channel of marketing by all three sample farms was channel-III in which produce is sold to the whole seller in field condition. Total quantity sold through channel-I, channel-II and channel-III was 7.14, 208.72 and 482.67 qt. / farm in small, medium and large farms respectively.

Cost and margin of various agencies in channel-I

It is simplest marketing channel in which no market intermediaries are involved in the producer sell directly their produce to consumer in field condition or sell their produce in nearly market like as retailer all cost like loading, unloading, weighting, transportation, bazaar fees etc beard by producer and the produce's share in consumer rupees was relatively high (95\%) as compare to other marketing channel. The present presented the table. 2 in which various marketing cost per quintal of channel-I is shown in the table and total marketing cost 35 rupees per quintal was find out.

\section{Cost and margin of various agencies in channel-II}

The second marketing channel producer sent their produce to commission agent to sold out,commission agent made auction and sell produce to retailer and take their commission from producer at the rate of $8 \%$. Retailer takes produce to nearby market and sold to consumer and earn their margin various cost and margins are shown in the table. 3 given below. In this type of marketing channel commission agent incurred lowest cost in terms of shop rent maintenance etc we can see from the table that total cost incurred by producer, commission agent, and retailer was 95,10 and 35 rupees per quintal respectively and net margin received by commission agent and retailer was 40 and 80 rupees per quintal respectively.

Costs and margins of various agencies in channel-III

In marketing channel no 3 the whole seller itself comes to producer and purchase their produce at field level directly and takes produce and dispose it in any other market in which he gain much margin from produce and various charges incurred by various intermediaries in process of marketing is shown in the table. 4 the charges incurred by producer, whole seller and retailer was 10,60 and 40 rupees per quintal respectively and net margin received by whole seller and retailer was 60 and 80 rupees per quintal respectively. The producers share in consumer rupees was $73.40 \%$ in this marketing channel. 
Constraints in production and marketing of Banana

Various problems in production and marketing of banana faced by sampled banana grower is analyzes through their opinion about various problems during the study period. The problems that faced in banana production and marketing is shown in the table no. 5,6 .

Table.1 Disposal pattern and marketable surplus of Banana (qt./farm)

\begin{tabular}{|l|l|l|l|l|l|l|}
\hline Farm & Total & \multicolumn{1}{|c|}{ Home } & Marketable & Channel & Channel & Channel \\
Size & production & consumption & Surplus & II & II & III \\
\hline Small & 210.00 & 2.00 & 208.00 & 40 & 58.00 & $\mathbf{1 1 0 . 0 0}$ \\
& $(100)$ & $(0.95)$ & $(99.04)$ & $(19.23)$ & $(27.88)$ & $\mathbf{( 5 2 . 8 8 )}$ \\
\hline Medium & 409.05 & 2.60 & 406.45 & - & 131.00 & $\mathbf{2 7 5 . 4 5}$ \\
& $(100)$ & $(0.63)$ & $(99.36)$ & & $(32.23)$ & $\mathbf{( 6 7 . 7 6 )}$ \\
\hline Large & 1243.68 & 3.50 & 1240.18 & - & 362.03 & $\mathbf{8 7 8 . 1 5}$ \\
& $(100)$ & $(0.28)$ & $(99.71)$ & & $(29.19)$ & $\mathbf{( 7 0 . 8 0 )}$ \\
\hline Overall & $\mathbf{7 0 1 . 3 9}$ & $\mathbf{2 . 8 4}$ & $\mathbf{6 9 8 . 5 4}$ & $\mathbf{7 . 1 4}$ & $\mathbf{2 0 8 . 7 2}$ & $\mathbf{4 8 2 . 6 7}$ \\
& $\mathbf{( 1 0 0 )}$ & $\mathbf{( 0 . 4 0 )}$ & $\mathbf{( 9 9 . 5 9 )}$ & $\mathbf{( 1 . 0 2 )}$ & $\mathbf{( 2 9 . 8 7 )}$ & $\mathbf{( 6 9 . 0 9 )}$ \\
\hline
\end{tabular}

Table. 2 Cost and margins of various agencies in the marketing of Banana/qt. in channel- I

\begin{tabular}{|l|l|c|}
\hline S/No. & Particulars/ Market functionaries & Amount (Rs./qt.) \\
\hline $\mathbf{1 .}$ & Marketing costs at producer level & \\
\hline & Loading,Unloading,Weighting & $\mathbf{1 0}$ \\
\hline & Transportation charge & $\mathbf{2 0}$ \\
\hline Other including Market charge & $\mathbf{5}$ \\
\hline Sub total & $\mathbf{3 5}$ \\
\hline Producers sale price & $\mathbf{7 0 0}$ \\
\hline Marketing cost & $\mathbf{3 5}$ \\
\hline Net price received & $\mathbf{6 6 5}$ \\
\hline Producers share in consumer rupees $(\%)$ & $\mathbf{9 5 .}$ \\
\hline & & $\mathbf{0 0}$ \\
\hline & Price Spread $(\%)$ & $\mathbf{5 . 0}$ \\
\hline
\end{tabular}


Table.3 Costs and margins of various agencies in the marketing of Banana/qt. in channel- II

\begin{tabular}{|c|c|c|}
\hline S/No. & Particulars/ Market functionaries & Amount (Rs./qt.) \\
\hline \multirow[t]{8}{*}{1.} & Marketing costs at producer level & \\
\hline & Loading,Unloading,Weighting & 10 \\
\hline & Transportation charge & 20 \\
\hline & Commission charge & 60 \\
\hline & Other & 5 \\
\hline & Sub total & 95 \\
\hline & Producers sell price & 750 \\
\hline & Net price received & 655 \\
\hline \multirow[t]{8}{*}{2.} & \multicolumn{2}{|c|}{ Cost incurred by Commission agent } \\
\hline & Loading,Unloading,Weighting & - \\
\hline & Transportation charge & - \\
\hline & Commission charge & - \\
\hline & Other & 10 \\
\hline & Commission charge & 60 \\
\hline & Marketing cost & 10 \\
\hline & Net price received & 50 \\
\hline \multirow[t]{11}{*}{3.} & \multicolumn{2}{|c|}{$\begin{array}{l}\text { Cost incurred by } \\
\text { retailer }\end{array}$} \\
\hline & Loading,Unloading,Weighting & 10 \\
\hline & Transportation charge & 20 \\
\hline & Others including market fees & 5 \\
\hline & Subtotal & 35 \\
\hline & Retailers purchase price & 750 \\
\hline & Marketing cost & 35 \\
\hline & Retailers sell price & 830 \\
\hline & Net margin & 80 \\
\hline & Producers share in consumer rupees $(\%)$ & $\begin{array}{l}77 . \\
56\end{array}$ \\
\hline & Price Spread (\%) & $\begin{array}{l}22 . \\
44\end{array}$ \\
\hline
\end{tabular}


Table. 4 Costs and margins of various agencies in the marketing of Banana/qt. in channel- III

\begin{tabular}{|c|c|c|}
\hline S/No. & Particulars/ Market functionaries & Amount (Rs./qt.) \\
\hline \multirow[t]{8}{*}{1.} & Marketing costs at producer level & \\
\hline & Loading,Unloading,Weighting & 10 \\
\hline & Transportation charge & - \\
\hline & Commission charge & - \\
\hline & Other & - \\
\hline & Subtotal & 10 \\
\hline & Producers sale price & $\begin{array}{l}7 \\
\text { 0 } \\
\text { 0 }\end{array}$ \\
\hline & Net price received & $\begin{array}{l}6 \\
9 \\
0\end{array}$ \\
\hline \multirow[t]{8}{*}{2.} & \multicolumn{2}{|c|}{ Cost incurred by Wholseller } \\
\hline & Loading,Unloading,Weighting & 10 \\
\hline & Transportation charge & 40 \\
\hline & Others including mandi fees & 10 \\
\hline & Subtotal & 60 \\
\hline & Whole sellers Purchase price & $\begin{array}{l}7 \\
0 \\
0\end{array}$ \\
\hline & Whole sellers sell price & $\begin{array}{l}8 \\
2 \\
0\end{array}$ \\
\hline & Whole sellers margin & 60 \\
\hline \multirow[t]{10}{*}{3.} & Cost incurred & tailer \\
\hline & Loading,Unloading,Weighting & 10 \\
\hline & Transportation charge & 20 \\
\hline & Others including mandi fees & 10 \\
\hline & Subtotal & 40 \\
\hline & Retailer Purchase price & $\begin{array}{l}8 \\
2 \\
0\end{array}$ \\
\hline & Retailer sell price & $\begin{array}{l}9 \\
4 \\
0\end{array}$ \\
\hline & Retailer margin & 80 \\
\hline & Producers share in consumer rupees (\%) & $\begin{array}{c}73.4 \\
0\end{array}$ \\
\hline & Price Spread (\%) & $\begin{array}{c}26.6 \\
0\end{array}$ \\
\hline
\end{tabular}


Table.5 Problems faced by sample farmers in production of Banana

\begin{tabular}{|c|c|c|c|c|c|c|}
\hline S/No. & Problems & Small & Medium & Large & Total & Rank \\
\hline 1. & $\begin{array}{l}\text { Shortage of } \\
\text { improved variety }\end{array}$ & $\begin{array}{l}15 \\
(75.00)\end{array}$ & $\begin{array}{l}34 \\
(70.83)\end{array}$ & $\begin{array}{l}37 \\
(84.09)\end{array}$ & $\begin{array}{l}86 \\
(76.78)\end{array}$ & II \\
\hline 2. & $\begin{array}{l}\text { Lack of latest } \\
\text { technical knowledge }\end{array}$ & $\begin{array}{l}13 \\
(65.00)\end{array}$ & $\begin{array}{l}37 \\
(77.08)\end{array}$ & $\begin{array}{l}31 \\
(70.45)\end{array}$ & $\begin{array}{l}81 \\
(72.32)\end{array}$ & IV \\
\hline 3. & $\begin{array}{l}\text { Scarcity of labour } \\
\text { during peak period }\end{array}$ & $\begin{array}{l}8 \\
(40.00)\end{array}$ & $\begin{array}{l}33 \\
(68.75)\end{array}$ & $\begin{array}{l}38 \\
(86.36)\end{array}$ & $\begin{array}{l}79 \\
(70.53)\end{array}$ & $\mathbf{V}$ \\
\hline 4. & $\begin{array}{l}\text { Problem of insect } \\
\text { and disease }\end{array}$ & $\begin{array}{l}6 \\
(30)\end{array}$ & $\begin{array}{l}22 \\
(45.83)\end{array}$ & $\begin{array}{l}18 \\
(40.90)\end{array}$ & $\begin{array}{l}46 \\
(41.07)\end{array}$ & VII \\
\hline 5. & $\begin{array}{l}\text { Problem of high } \\
\text { value of seed }\end{array}$ & $\begin{array}{l}20 \\
(100)\end{array}$ & $\begin{array}{l}40 \\
(83.33)\end{array}$ & $\begin{array}{l}32 \\
(72.72)\end{array}$ & $\begin{array}{l}92 \\
(82.14)\end{array}$ & I \\
\hline 6. & $\begin{array}{l}\text { Problem of } \\
\text { sufficient water }\end{array}$ & $\begin{array}{l}4 \\
(20)\end{array}$ & $\begin{array}{l}8 \\
(16.66)\end{array}$ & $\begin{array}{l}6 \\
(13.63)\end{array}$ & $\begin{array}{l}18 \\
(16.07)\end{array}$ & VIII \\
\hline 7. & $\begin{array}{l}\text { Crop damage due to } \\
\text { environmental } \\
\text { factor (cyclone) }\end{array}$ & $\begin{array}{l}16 \\
(80.00)\end{array}$ & $\begin{array}{l}38 \\
(79.16)\end{array}$ & $\begin{array}{l}31 \\
(70.45)\end{array}$ & $\begin{array}{l}85 \\
(75.89)\end{array}$ & III \\
\hline 8. & $\begin{array}{l}\text { Problem of power } \\
\text { Cut }\end{array}$ & $\begin{array}{l}14 \\
(70.00)\end{array}$ & $\begin{array}{l}28 \\
(38.33)\end{array}$ & $\begin{array}{l}26 \\
(59.09)\end{array}$ & $\begin{array}{l}68 \\
(60.71)\end{array}$ & VI \\
\hline
\end{tabular}

Table.6 Problems faced by sample farmers in marketing of Banana

\begin{tabular}{|c|c|c|c|c|c|c|}
\hline $\begin{array}{l}\text { S/ } \\
\text { No. }\end{array}$ & Problems & Small & $\begin{array}{l}\text { Mediu } \\
\text { m }\end{array}$ & Large & Total & $\begin{array}{l}\text { Ran } \\
\mathbf{k}\end{array}$ \\
\hline 1. & $\begin{array}{l}\text { Lack } \\
\text { processing } \\
\text { industries } \\
\text { on Banana }\end{array}$ & $\begin{array}{l}20 \\
(100)\end{array}$ & $\begin{array}{l}48 \\
(100.00)\end{array}$ & $\begin{array}{l}44 \\
(100)\end{array}$ & $\begin{array}{l}112 \\
(100)\end{array}$ & I \\
\hline 2. & $\begin{array}{l}\text { Lack of regulated } \\
\text { and co-operative } \\
\text { market }\end{array}$ & $\begin{array}{l}15 \\
(75)\end{array}$ & $\begin{array}{l}37 \\
(77.08)\end{array}$ & $\begin{array}{l}32 \\
(72.72)\end{array}$ & $\begin{array}{l}84 \\
(75)\end{array}$ & III \\
\hline 3. & $\begin{array}{l}\text { Dependence } \\
\text { on middle } \\
\text { man for disposal }\end{array}$ & $\begin{array}{l}16 \\
(80)\end{array}$ & $\begin{array}{l}48 \\
(100.00)\end{array}$ & $\begin{array}{l}44 \\
(100)\end{array}$ & $\begin{array}{l}108 \\
(96.42)\end{array}$ & II \\
\hline 4. & Less no. of & $\begin{array}{l}8 \\
(40)\end{array}$ & $\begin{array}{l}25 \\
(52.08)\end{array}$ & $\begin{array}{l}29 \\
(65.90)\end{array}$ & $\begin{array}{l}62 \\
(55.35)\end{array}$ & VI \\
\hline 5. & $\begin{array}{l}\text { Lack of awareness } \\
\text { about market } \\
\text { Information }\end{array}$ & $\begin{array}{l}17 \\
(85)\end{array}$ & $\begin{array}{l}31 \\
(64.58)\end{array}$ & $\begin{array}{l}23 \\
(52.27)\end{array}$ & $\begin{array}{l}71 \\
(63.39)\end{array}$ & IV \\
\hline 6. & $\begin{array}{l}\text { Due to high } \\
\text { transportation } \\
\text { charges }\end{array}$ & $\begin{array}{l}8 \\
(40)\end{array}$ & $\begin{array}{l}23 \\
(47.91)\end{array}$ & $\begin{array}{l}27 \\
(61.36)\end{array}$ & $\begin{array}{l}58 \\
(51.78)\end{array}$ & $\mathbf{V}$ \\
\hline
\end{tabular}



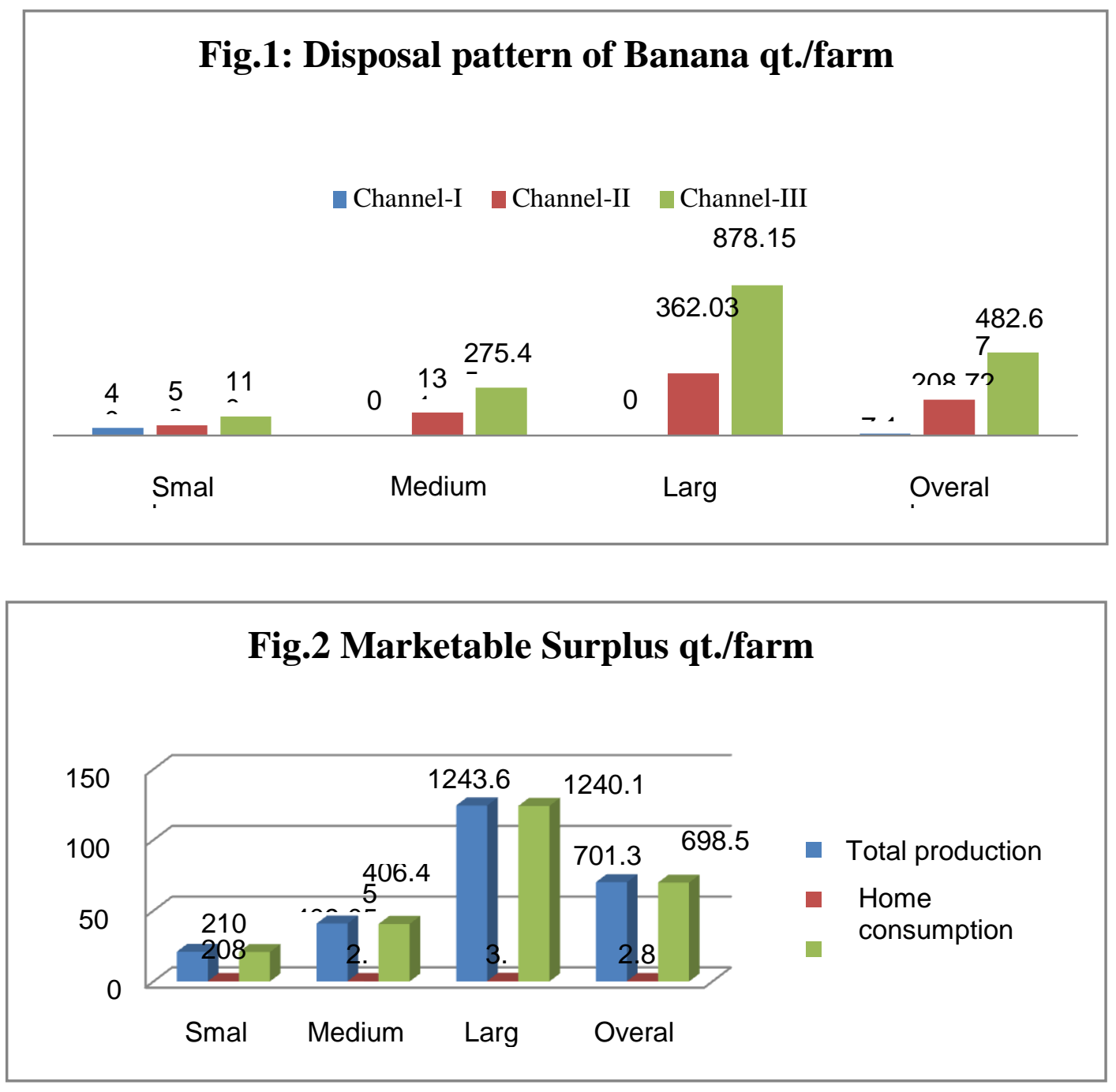

Fig.3 Producers share in consumer rupees

- Producers share in consumes

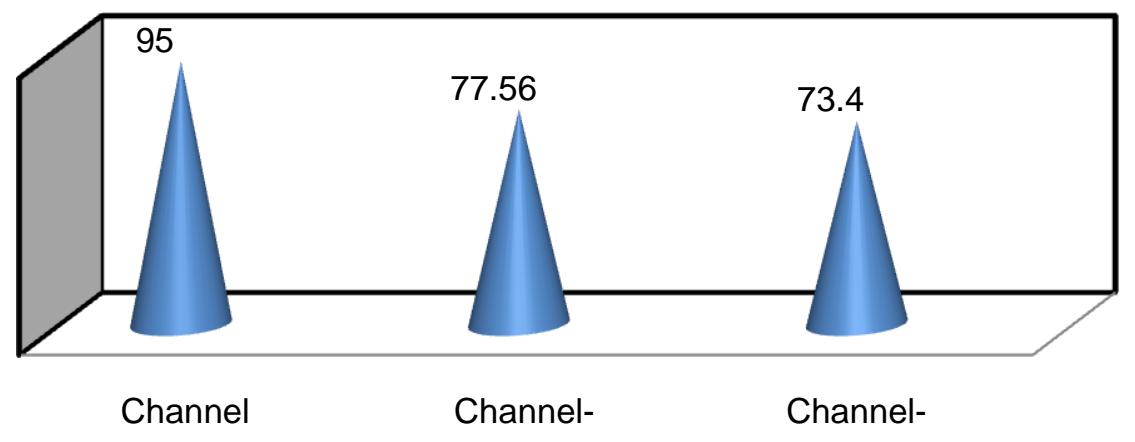




\section{Problems related to production of banana}

As per the table 4.14 the first and major problem faced by farmers in study area is high value of seed which is necessary to get higher production of crop and this problem is reported by $82.14 \%$ of sample farmers. Another constraint which is reported $76.78 \%$ sampled farmer in study area is shortage of improved variety, Banana crop highly affected from high speed wind about $75.89 \%$ of sample farmers felt these type of problem . To get higher production and productivity is important to the package of practices of banana cultivation but due to un sufficient support to provide technical knowledge is a constraint which is reported by $72.32 \%$ of sampled farmers. Banana cultivation is highly labour intensive and scarcity of labour during peak period is one of another major constraints faced by $70.53 \%$ of farmers among sample farmers in the study area. Banana crop required high irrigation which is effected due to power cut in study area, 60.71 $\%$ of farmers faced problem of power cut Drip irrigation system are used in cultivation of banana which used irrigation water efficiently therefore very few farmer 16.07 per cent faced the problem of sufficient water.

\section{Problems related to marketing of banana}

Problem related to marketing of banana is presented in table 4.15 in the study area almost all farmers faced the problem of unavailability of processing industry and cold storage of banana. . Due to bulk production farmers are highly depend on middleman to sell their produce about $96.42 \%$ of the sampled farmers says that dependency on middleman is a major constraint in marketing of banana

To get maximum price for their crop farmer need regulated and co operative is needed by $75 \%$ of sampled farmers its necessary to get in touch of updated market news $63.39 \%$ of sampled farmers faced the problem of less information about market information and $51.78 \%$ of the farmers faced the transportation problem in the study area

In conclusion, an efficient marketing channel and system is crucial for successful marketing of banana in terms of yield and income. Proper marketing information and facilities will ultimately improvise the producer's share in consumer's price. Farmers are needed to be acknowledged with recent research techniques under this crop which will help them to improvise in production business. The researchers and extension agencies should contribute to narrow the gap between potential and actual yield.

\section{References}

Arulkodi, R. 2003. Marketing of Banana in Trichirapalli District. Unpublished Ph.D. Thesis Submitted to Manonmaniam Sundaranar University, Tirunelveli., pp: 210.

Ashok, A., Liberalisation, N. and Globalisation. 2004. Issues in Agricultural Marketing. Southern Economist., 42(19), pp: 5.

Deepak, K. and Kumar, A. 2014. A study on the problems of agricultural marketing of banana in Thoothukudi district Tamil Nadu. International Journal in Commerce, IT \& Social Sciences., 1 (3). pp: 2394-5702

Deshmukh, D. Bornare, S.P. and Kumar, P. 2013. Constraints in Banana Marketing and Scope of improvement: A case study for Jalgaon Region. International Journal of Science, Spirituality, Business and Technology., 2(3), pp: 3440.

Gunasekaran, M. 2016. Production and Marketing Problems Faced by Banana Farmers in Karur District. Asia Pacific 
Journal of Research., pp: 2320- 5504.

More, S.S., Dudhate, D.G. and Kalalbandi, B. 2008. Constraints faced by Banana Growers in Production Marketing and Finance of Banana Cultivation. International Journal of Agricultural Sciences, 4(2): 562-564.

Muthupandi, V. 2009. Cultivation and Marketing Problems of Banana in Tamil Nadu, A Study with Reference to Madurai District. Ph.D. Thesis submitted to Kamaraj University Madurai.

Naveen, B., Jayaram, Dhananjaya, Swamy, P.S., Ramesh, G.B. and Raghavendra, D.V. 2015. Marketing channels and price spread of banana in Chikkaballapur district of Karnataka. International Research Journal of Agricultural Economics and Statistics., 18-22.

Raman, M.S. and Umanath, M. 2016. Production and marketing of banana in
Tiruchirapalli district of Tamil Nadu: an economic analysis. International Research Journal of Agricultural Economics and Statistics., 7(1): 67-75.

Sangolkar, U.B. (2012). A study of Banana production and marketing in Wardha district of Maharashtra. Internat. Res. J. agric. Eco. \& Stat., 3 (1): 72-76.

Sarode, S.C. 2009. Economics of banana marketing in Jalgaon district: An analysis across alternative channels. African Journal of Marketing Management., 1(5):128-132.

Verma, A. and Singh, K.P. 2002. Market Analysis of Fruits and Vegetables. A Case Study in Patna Block of U.P. The Bihar Journal of Agricultural Marketing., 10 (2): 119-122.

Verma, A and Singh, K.P., 2003. Banana Marketing Study. The Bihar Journal of Agricultural Marketing., 11(1/6): 1-2.

\section{How to cite this article:}

Ashish Patel, Shashank Sharma, Anjali Verma and Yogeshwari Sahu. 2020. Marketing Pattern and Constraints of Banana Production in Bemetara District of Chhattisgarh, India. Int.J.Curr.Microbiol.App.Sci. 9(06): 1951-1960. doi: https://doi.org/10.20546/ijcmas.2020.906.241 